\title{
EFFECT OF DIFFERENT HOUSING SYSTEMS AND SEASONAL VARIATIONS ON GROWTH PERFORMANCE, PHYSIOLOGICAL PARAMETERS AND ECONOMIC EFFICIENCY OF FRIESIAN CALVES
}

M. S. Sayah, S. A. Ibrahim, A. M. El-Gafarawy, A. A. Sheta and A. M. A. Salama

Cattle Breeding Department, Animal Production Research Institute, Agricultural Research Center, Giza, Egypt

\section{SUMMARY}

A total of 16 male Friesian calves at 6-7 months of age and averaged $123 \mathrm{~kg}$ were used to study their growth performance and physiological responses during three seasons (winter, spring and summer) in two different housing systems (tie-stall and loose animals) under the same environmental conditions. Live body weights were recorded monthly to estimate body weight gain ( $B W G)$ and daily weight gain (DWG). Feed and water consumption were recorded weekly to estimate dry matter intake (DMI) and water intake (WI). Air temperature (AT) was measured four times per day, while relative humidity $(R H)$ was measured twice per day. Blood samples were collected monthly to evaluate total protein (TP), total lipids (TL), glucose, albumin, globulin and thyroxin hormone $\left(T_{4}\right)$. Values of rectal temperature $(R T)$, skin temperature $(S T)$ and respiration rate $(R R)$ were recorded biweekly. In addition, the study estimated the economic efficiency under the two different housing systems. Results of housing effect showed highly significant differences $(P<0.01) B W G$, $D W G, W I, R T$ and RR.. However, the results of DMI, ST and blood compositions showed insignificant differences between the two housing systems. The results showed also significant seasonal differences $(P<0.01)$ for $B W G, D W G, D M I, W I$, $R T, S T, R R$ and $T_{4}$. There were highly significant correlations between animal responses and the environmental conditions. It could be concluded that keeping animals in tie-stall system inside a fully shaded barn having dry concrete floor with good drainage and well-ventilated area gives better growth performance than keeping animals in loose system under the same environmental conditions. Moreover, the effect of different housing systems is limited mainly to growth performance and body reaction without influencing blood composition. The total revenue was increased in tie-stall group compared with loose animal group (3.80 and 2.97, respectively).

Keywords: tie-stall, loose housing, seasonal variations, Friesian, growth rate, blood composition, economic efficiency

INTRODUCTION

The major requirements of the animal housing can be translated into specifications for climate, space, allowances, ventilation and shelter or pen design

Issued by The Egyptian Society of Animal Production 
(Lawrence, 1994). Housing system is considered as an important factor affecting animal performance and behavior. Dairy calf housing, properly managed, can assure the breeder of healthy and fast growing calves for replacement or market with a minimum trouble or calf loss. Housing models and systems had a significant effect on growth rates of calves (Pusillo et al., 1991 and Mitlohner et al., 2002). However, other authors found insignificant effect of housing on growth rates (Terosky et al., 1997; Prawl et al., 1998 and Chua et al., 2002). This contradiction is, most probably, due to the differences under investigation by the authors, and the surrounding environments.

The stall barn remains the choice of the majority of dairymen in Egypt having fattening herds. However, increases in dairy herd sizes have been a major factor to convert from stall barns to free stall housing. Terosky et al. (1997) concluded that there were no effects of housing design on body weight (BW), daily gain (DG), carcass weight, or dressing percentage. In addition, Prawl et al. (1998) found that steers with less space had lower dry matter intake but they gained at rate similar to steers fed in larger pens. However, Pusillo et al. (1991) indicated that housing system significantly influenced cattle feedlot performance without influencing body composition.

Various authors studied the physiological reaction of different cattle breeds to natural or artificial environmental conditions. There is a great deal of agreement between their results. Cattle body reactions were related to temperature humidity index (THI) (West, 2003). Rectal temperature, skin temperature and respiration rate showed high values of correlation with air temperature (Shafie and El-Sheikh Aly, 1970; Kobeisy, 1983; Sayah, 2005 and Ashour et al., 2007). Body reaction values increased linearly with increasing air temperature. The difference between normal and lethal body temperature is in the order of $15-25{ }^{\circ} \mathrm{C}$ in the cold and of only around $3-6{ }^{\circ} \mathrm{C}$ in the heat. This explains why cold represents less problem than heat (Collier et al., 1982). However, outside of the comfort zone, the animal experiences stress to maintain homeothermy (Nardone et al., 2006). Changes in blood metabolite levels that due to exposing animals to air temperature have been studied by several authors (Yousef and Johnson, 1966; Daader et al., 1989; Shaffer et al., 1981; Abdel-samee et al., 1996; Sayah, 2005 and Ashour et al., 2007). The results showed different values; this may due to the different surrounding environments under investigations.

The main objectives of this study were to evaluate the effects of housing systems and seasonal variations on growth performance and physiological responses of Friesian young bulls kept in two different housing systems; tie-stall system and loose system housed inside a wide, good-ventilated and lighted barn. Moreover, the study estimated the economical efficiency of rearing young bulls under the two different housing systems.

\section{MATERIALS AND METHODS}

\section{Animals and Management}

A total of 16 healthy male Friesian calves at 6-7 months of age and averaged 123 $\mathrm{kg}$ live body weight belonging to Sakha Experimental Station, Animal Production Research Institute, Ministry of Agriculture, Egypt, were selected and divided into two equal groups according to their age and weight to be used in this study. 
The first group of animals was loose and the second group was tied. Both groups were kept in a semi-open barn under the same environmental conditions in three seasons; winter as a cold weather (December-February), spring (March-May) as a moderate weather and summer (June-September) as a hot weather. The two animal groups were kept in a fully shaded barn $(30 \mathrm{~m}$ length X $7.5 \mathrm{~m}$ width) (Fig. 1 and Plate 1), which was roofed with an asbestos sheet at $3.5 \mathrm{~m}$ height on a concrete floor and a proper drainage. The barn was divided into tow equal parts $(15 \mathrm{~m}$ deep X $6.5 \mathrm{~m}$ width), each part for each animal group. The allocated space for each loose animal was $12 \mathrm{~m}^{2}$. The barn was surrounded with brick walls having wide ventilation openings (about $60 \%$ of the barn).

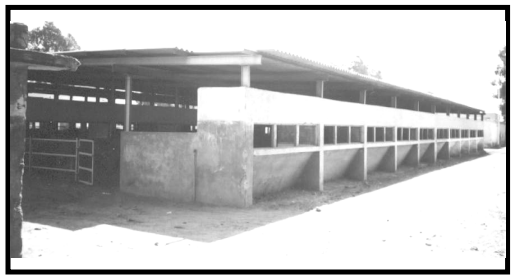

Fig. 1. Semi-open barn

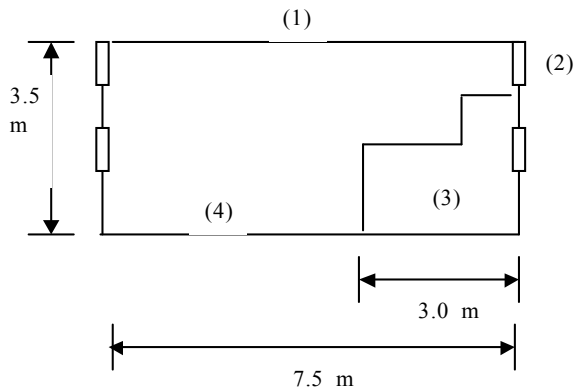

Plate 1. Front Layout of semi-open barn

(1) Asbestos roof, (2) Ventilation opening, (3) A short wall (4) Concrete floor

The animals were offered a daily allowance of concentrate ration in accordance with their body weight at the rate recommended by NRC (1981) once a day in the morning according to the farm routine. Beside that, the animals had fresh berseem in winter and spring seasons, and they had berseem hay in summer. Moreover, the calves had daily access to ad libitum rice straw. At the end of the test day, the residual ration was weighed and recorded as a group feeding. Then, the dry matter intake (DMI) was calculated based on the dry matter percentage of every feedstaff intake in terms of $\mathrm{Kg} / \mathrm{head} /$ day. In addition, the relative DMI was calculated based on the metabolic body weight $(\mathrm{MBW})$ in $\left(\mathrm{W}^{0.75}\right)$ and tabulated as DMI $(\mathrm{g} / \mathrm{Kg} \mathrm{MBW})$.

Fresh water for animal drinking was offered in a measured water trough, which was used to determine the water consumption of animals in the test day. At the end of the test days, the absolute water intake of calves recorded based on the residual water after drinking, where it was subtracted from the offered water and estimated in terms of $\mathrm{L} / \mathrm{head} /$ day. The relative water intake was calculated based on the metabolic body weight $\mathrm{MBW}$ in $\left(\mathrm{W}^{0.75}\right)$ and tabulated as $\mathrm{WI}(\mathrm{ml} / \mathrm{kg} \mathrm{MBW})$. 


\section{Experimental Procedures}

The technical procedures were carried out at monthly intervals for the two housing systems at the same day. Some physiological parameters were taken twice and others were taken once during the experimental day.

\section{Environmental Conditions and Physiological Parameters}

Air temperature $\left(\mathrm{AT},{ }^{\circ} \mathrm{C}\right.$ ) was recorded at 08:00 hr, 14:00 hr and 18:00 hr beside the minimum- maximum temperature using alcohol and minimum- maximum thermometers. Relative humidity ( $\mathrm{RH}, \%)$ was recorded twice a day at 08:00 $\mathrm{hr}$ and 14:00 $\mathrm{hr}$ using electronic thermo-hygrometer. The following equation was used to determine the temperature-humidity index (THI) as an indicator of adverse climatic conditions (AETG, 1980).

$\mathrm{THI}=(1.8 * \mathrm{~T}+32)-(0.55-0.0055 \mathrm{RH})(1.8 * \mathrm{~T}-58)$

Where: $\quad \mathrm{T}$ is air temperature $\left({ }^{\circ} \mathrm{C}\right)$ and $\mathrm{RH}$ is the relative humidity $(\%)$

\section{Blood Compositions, Body Reactions and Body Weight Performance}

Blood samples were taken monthly from five animals in each group. These samples were centrifuged at 3000 r.p.m. for 15 minutes to separate blood plasma which was stored at $-20{ }^{\circ} \mathrm{C}$ till relevant hormones and metabolites assay. Total protein $(\mathrm{TP}, \mathrm{g} / \mathrm{dl})$, albumin $(\mathrm{g} / \mathrm{dl})$, total lipids $(\mathrm{TL}, \mathrm{g} / \mathrm{l})$, glucose $(\mathrm{mg} / \mathrm{dl})$ and thyroxine hormone $\left(\mathrm{T}_{4}, \mu \mathrm{g} / \mathrm{dl}\right)$ concentrations were determined using special kits according to the procedures outlined by the manufacturers. Globulin concentration $(\mathrm{g} / \mathrm{dl})$ was calculated as a result from the subtraction between TP and albumin concentrations.

Rectal temperature (RT) was measured using a digital thermometer. The measurements were recorded to the nearest $0.1{ }^{\circ} \mathrm{C}$. Skin temperature (ST) was measured using an infrared thermometer at the fore-flanks region. Respiration rate (RR) was determined by counting the flank's movements per minute (breaths/minute) using stopwatch.

Live body weight (LBW, kg) was recorded monthly in the morning before feeding and watering the animals. In addition, metabolic body weight was calculated according to $\left(\mathrm{W}^{0.75}\right)$. Moreover, daily weight gain (DWG) was calculated according to the body weight gain during the three seasons: winter for 83 days, spring for 91 days and summer for 108 days until the animals reached its final weight $(370.3 \mathrm{~kg}$ for the loose animals and $412.3 \mathrm{~kg}$ for the tie stall as averages). The numbers of observation were obtained from 24 readings for each housing system for every season.

\section{Statistical Analysis}

Statistical analyses of data were carried out applying the package of SAS (1996) according to the following models:

$$
\mathrm{Y}_{\mathrm{ijk}}=\mu+\mathrm{H}_{\mathrm{i}}+\mathrm{S}_{\mathrm{j}}+\mathrm{e}_{\mathrm{ijk}}
$$

Where: $\mathrm{Y}_{\mathrm{ijk}}$ is the studied dependent variable,

$\mu$ is the overall mean,

$\mathrm{H}_{\mathrm{i}}$ is the effect of housing; two levels, ( $\mathrm{i}, 1$ \& 2)

$\mathrm{S}_{\mathrm{j}}$ is the effect of season; three levels, $(\mathrm{j}, 1,2, \& 3)$ and

$\mathrm{e}_{\mathrm{ijk}}$ is random residual effect. 


\section{RESULTS AND DISCUSSION}

\section{Environmental Conditions}

Air temperature $\left(\mathrm{AT},{ }^{\circ} \mathrm{C}\right)$, relative humidity $(\mathrm{RH} \%)$ and the temperature humidity index (THI) inside the semi-open barn during three experimental seasons are shown in Table (1).

The results showed that there were great seasonal and diurnal differences in the climatic conditions. The highest air temperature was found in summer compared with winter and spring. According to Johnson (1987), the upper critical THI for HolsteinFriesian cattle is 72 . Therefore, Friesian young bulls were suffering from heat stress at 08:00 $\mathrm{hr}$ and 14:00 $\mathrm{hr}$ in summer (75.20 and 81.30, respectively) and at 14:00 $\mathrm{hr}$ in spring (72.10). Thus, the summer hot condition is apt to impose extra stress on the animals, which reflected on the animal performance severely. The THI values in winter either in the morning or in the afternoon (54.70 and 66.93, respectively) showed the lowest values than summer and spring seasons at the same daytimes. Mader et al. (2006) stated that although knowledge of THI alone is beneficial in determining the potential for heat stress, wind speed and solar radiation adjustments to the THI would be more accurately assess animal discomfort.

Table 1. Means \pm S.E. of air temperatures $\left(\mathrm{AT},{ }^{\circ} \mathrm{C}\right)$, relative humidity $(\mathrm{RH} \%)$ and temperature humidity index (THI) at 08:00 hr, 14:00 hr and 18:00 hr as affected by seasonal variations

\begin{tabular}{cccc}
\hline & Winter & Spring & Summer \\
\hline AT ( ${ }^{\mathbf{C}}$ ) & & & \\
Min. & $09.00 \pm 0.8$ & $14.50 \pm 0.8$ & $20.75 \pm 0.8$ \\
$\mathbf{0 8 : 0 0} \mathbf{~ h r}$ & $13.00 \pm 0.9$ & $19.25 \pm 0.9$ & $25.25 \pm 0.9$ \\
$\mathbf{1 4 : 0 0} \mathbf{~ h r}$ & $23.00 \pm 1.4$ & $26.00 \pm 1.4$ & $33.50 \pm 1.4$ \\
$\mathbf{1 8 : 0 0} \mathbf{~ h r}$ & $17.25 \pm 0.8$ & $22.00 \pm 0.8$ & $26.50 \pm 0.8$ \\
$\mathbf{R H \%}$ & & & \\
$\mathbf{0 8 : 0 0 ~ h r}$ & $77.00 \pm 2.8$ & $70.33 \pm 2.3$ & $74.00 \pm 2.8$ \\
$\mathbf{1 4 : 0 0} \mathbf{~ h r}$ & $55.00 \pm 5.4$ & $41.00 \pm 4.4$ & $45.00 \pm 5.4$ \\
$\mathbf{T H I}$ & & & \\
$\mathbf{0 8 : 0 0} \mathbf{~ h r}$ & $54.70 \pm 0.8$ & $63.18 \pm 4.9$ & $75.20 \pm 2.8$ \\
$\mathbf{1 4 : 0 0} \mathbf{~ h r}$ & $66.93 \pm 1.1$ & $72.10 \pm 3.8$ & $81.30 \pm 0.5$ \\
\hline
\end{tabular}

(Min.) Minimum Air Temperature, (hr) Hour

\section{Growth Performance}

\subsection{Feed and water intakes}

The effects of different housing systems and seasonal variations on dry matter intake (DMI, kg) and water intake (WI, L) are presented in Table (2).

The results showed that there were no significant differences between the effects of tie-stall and loose housing systems on DMI during the three seasons. However, there were significant seasonal differences $(P<0.01)$ between the effects of winter, spring and summer on DMI in terms of $\mathrm{g} / \mathrm{kg} \mathrm{LBW}$, summer had the lowest value (26.71g) compared with the other values in winter and spring $(29.44 \mathrm{~g}$ and $28.53 \mathrm{~g}$, respectively). There was highly negative correlation coefficient $(-0.62)$ between DMI and AT. This result is in agreement with Morrison (1983) who mentioned that livestock performance is affected by heat stress because an animal having difficulty 
in losing heat will decrease its heat production by lowering, feed intake. NRC (1981) reported that the increases in respiratory rate and water consumption as well as decreased rumen motility; all contribute towards reducing appetite and intake. It established that high environmental temperature stimulates the peripheral thermal receptors to transmit suppressive nerve impulses to the appetite center in the hypothalamus causing decrease in the feed consumption to minimize thermal load. West (2003) stated that increasing air temperature, temperature-humidity index and rising rectal temperature above critical thresholds are related with decreasing dry matter intake (DMI).

Table 2. Means \pm S.E of dry mater intake per live body weight (DMI, g/kg LBW), dry mater intake per metabolic body weight (DMI, g/kg MBW), water intake per live body weight (WI, $\mathrm{ml} / \mathrm{kg} \mathrm{LBW}$ ) and water intake per metabolic body weight (WI, ml/kg MBW) and their averages of young Friesian bulls kept in different housing systems

\begin{tabular}{cccc}
\hline \multirow{2}{*}{ Item/Housing types } & \multicolumn{3}{c}{ Seasons } \\
\cline { 2 - 4 } DMI (g/kg LBW) & Winter & Spring & Summer \\
Tie-Stall system & $29.52^{\mathrm{a}} \pm 0.4$ & $28.13^{\mathrm{a}} \pm 0.3$ & $26.29^{\mathrm{a}} \pm 0.2$ \\
Loose system & $29.37^{\mathrm{a}} \pm 0.4$ & $28.93^{\mathrm{a}} \pm 0.3$ & $27.13^{\mathrm{a}} \pm 0.2$ \\
$\quad$ Average & $29.44^{\mathrm{a}} \pm 0.3$ & $28.53^{\mathrm{b}} \pm 0.2$ & $26.71^{\mathrm{c}} \pm 0.2$ \\
DMI (g/kg MBW) & & & \\
Tie-Stall system & $110.94^{\mathrm{a}} \pm 3.1$ & $116.98^{\mathrm{a}} \pm 2.1$ & $117.61^{\mathrm{a}} \pm 1.5$ \\
Loose system & $107.77^{\mathrm{a}} \pm 3.1$ & $117.82^{\mathrm{a}} \pm 2.1$ & $119.54^{\mathrm{a}} \pm 1.5$ \\
$\quad$ Average & $109.36^{\mathrm{b}} \pm 2.2$ & $117.39^{\mathrm{a}} \pm 1.5$ & $118.58^{\mathrm{a}} \pm 1.1$ \\
WI (ml/kg LBW) & & & \\
Tie-Stall system & $49.79^{\mathrm{b}} \pm 1.7$ & $60.24^{\mathrm{b}} \pm 1.6$ & $69.08^{\mathrm{b}} \pm 1.4$ \\
Loose system & $69.42^{\mathrm{a}} \pm 1.7$ & $75.97^{\mathrm{a}} \pm 1.6$ & $87.13^{\mathrm{a}} \pm 1.4$ \\
Average & $59.61^{\mathrm{c}} \pm 1.2$ & $68.11^{\mathrm{b}} \pm 1.1$ & $78.11^{\mathrm{a}} \pm 1.0$ \\
WI (mI/kg MBW) & & & \\
Tie-Stall system & $185.18^{\mathrm{b}} \pm 5.7$ & $251.13^{\mathrm{b}} \pm 6.2$ & $310.58^{\mathrm{b}} \pm 4.9$ \\
Loose system & $254.23^{\mathrm{a}} \pm 5.7$ & $309.27^{\mathrm{a}} \pm 6.2$ & $381.03^{\mathrm{a}} \pm 4.9$ \\
Average & $219.71^{\mathrm{c}} \pm 4.1$ & $280.20^{\mathrm{b}} \pm 4.4$ & $345.80^{\mathrm{a}} \pm 3.4$ \\
\hline
\end{tabular}

* ${ }^{\mathrm{a}, \mathrm{b}}$ Means within each housing system and ${ }^{\mathrm{a}, \mathrm{b}, \mathrm{c}}$ Means within each season with different superscripts are significantly different $(P<0.01)$

Furthermore, as far as DMI in terms of $\mathrm{g} / \mathrm{kg} \mathrm{MBW}$, the highest value was obtained in summer (118.58 g), while the lowest value was obtained in winter (109.36 g), spring had an approximate value (117.39 g) to summer. This means that animal under hot conditions needs more metabolic energy to increase its body weight one $\mathrm{kg}$ than animal under cold conditions. This result may due to the higher efficiency of feed utilization in winter than in summer.

Water intake results showed significant differences $(P<0.01)$ between the two housing systems, where the loose animals consumed more water than tie-stall animals in terms of $\mathrm{ml} / \mathrm{kg}$ MBW during winter, spring and summer (254.23 vs. $185.18,309.27$ vs. 251.13 and 381.03 vs. $310.58 \mathrm{ml} / \mathrm{Kg} / \mathrm{MBW}$, respectively). The 
high values of WI in the loose system may due to the continuous movement of the animals. Moreover, the results showed that the water consumption of young bulls was affected severely by the high AT, where WI values were increasing as AT increases. There was highly positive correlation coefficient (0.69) between WI and AT. Therefore, the need for water was seriously important, perhaps more than the need for other nutrients. Ashour (1990) reported that water intake is affected by several factors such as: increase of dry matter intake, quality of the feed intake, level of $\mathrm{Na} \mathrm{Cl}$. However, climate is the most important factor affecting water intake, it has a dramatic affect on water consumption. El-Nouty (1996) stated that thermal stress causes a rise in core temperature in turn activates heat loss mechanism via panting and sweating. This causes dramatic increase in water intake and urine output. Ashour et al. (2007) reported that the increase in WI in hot condition reflects the physiological role of water in counteracting heat stress by increasing water vaporization through skin and respiratory surface. The same trend was also observed in WI ( $\mathrm{ml} / \mathrm{kg} \mathrm{MBW})$.

\subsection{Growth Rate}

The effects of different housing systems and seasonal variations on live body weight (LBW, kg), metabolic body weight (MBW, kg), body weight gain (BWG, kg) and daily weight gain (DWG, g) are presented in Table (3).

The results showed that the BWG and DWG values were affected by the different housing systems. The tie-stall housing system had significantly higher $(P<0.01)$ values of BWG and DWG during the three seasons compared with the loose housing system under the same environmental conditions. This result is in agreement with Sayah (2005) who found that animals became adapted to its environment after exposing to severe climatic conditions. Bianca (1965) reported that the decreasing of the anabolism occurs, particularly, in the metabolizable energy for both maintenance and gain weight. On the contrary Pusillo et al. (1991) indicated that open lot with overhead shelter caused higher average daily gain than feedlot cattle in open-front confinement building.

The results showed also seasonal effects for the three experimental seasons, the highest value of BWG was obtained in spring $(101.63 \mathrm{~kg})$, while the lowest value was obtained in winter $(67.21 \mathrm{~kg})$. The values of DWG had the same trend of BWG. The BWG and DWG in summer decreased from $101.61 \mathrm{~kg}$ to 99.65 and from 1.12 to $0.92 \mathrm{~kg}$, respectively. This result is due to that animal in summer were under heat stress, which reflected on the body performance and resulted in lower growth rate. This result is in agreement with Daader et al. (1989) who reported that the total body weight was decreased significantly in hot summer. Sakaguchi and Gaughan (2002) reported that exposing animals to high or low air temperature for a long time results in decreasing the daily weight gain. On the contrary, Muhamed et al. (1983) found that steers gained more $(P<0.05)$ in summer than in winter, especially for calves that reared outdoors.

The results showed also that the LBW values were affected significantly $(P<0.01)$ by the housing system. The tie-stall system had the highest values of LBW during the three seasons; winter, spring and summer (195.17, 305.58 and $412.33 \mathrm{~kg}$, respectively) compared with the loose system (185.17, 277.87 and $370.29 \mathrm{~kg}$, respectively). The same trend was also observed in MBW. 
Table 3. Means \pm S.E of live body weight (LBW, kg), body weight gain (BWG, kg) and daily weight gain (DWG, kg), and their averages of young Friesian bulls kept in different animal housing systems

\begin{tabular}{cccc}
\hline \multirow{2}{*}{ Item/Housing types } & Winter & Spring & Summer \\
\cline { 2 - 4 } & & & \\
\hline LBW (Kg) & $195.17^{\mathrm{a}} \pm 7.7$ & $305.58^{\mathrm{a}} \pm 8.2$ & $412.33^{\mathrm{a}} \pm 8.5$ \\
Tie-Stall system & $185.17^{\mathrm{a}} \pm 7.7$ & $277.87^{\mathrm{b}} \pm 8.2$ & $370.29^{\mathrm{b}} \pm 8.5$ \\
Loose system & $190.17^{\mathrm{c}} \pm 5.4$ & $291.73^{\mathrm{b}} \pm 5.8$ & $391.31^{\mathrm{a}} \pm 6.0$ \\
Average & & & \\
MBW (Kg) & $52.04^{\mathrm{a}} \pm 1.6$ & $72.96^{\mathrm{a}} \pm 1.5$ & $91.40^{\mathrm{a}} \pm 1.4$ \\
Tie-Stall system & $50.03^{\mathrm{a}} \pm 1.6$ & $67.95^{\mathrm{b}} \pm 1.5$ & $84.33^{\mathrm{b}} \pm 1.4$ \\
Loose system & $51.04^{\mathrm{c}} \pm 1.1$ & $70.46^{\mathrm{b}} \pm 1.1$ & $87.86^{\mathrm{a}} \pm 1.0$ \\
Average & & & \\
BWG (Kg) & $72.25^{\mathrm{a}} \pm 3.6$ & $110.42^{\mathrm{a}} \pm 4.2$ & $106.47^{\mathrm{a}} \pm 4.1$ \\
Tie-Stall system & $62.12^{\mathrm{a}} \pm 3.6$ & $92.71^{\mathrm{b}} \pm 4.2$ & $92.14^{\mathrm{b}} \pm 4.1$ \\
Loose system & $67.21^{\mathrm{b}} \pm 2.5$ & $101.63^{\mathrm{a}} \pm 3.3$ & $99.65^{\mathrm{a}} \pm 3.1$ \\
Average & & & \\
DWG (Kg) & $0.87^{\mathrm{a}} \pm 0.0$ & $1.22^{\mathrm{a}} \pm 0.0$ & $0.98^{\mathrm{a}} \pm 0.1$ \\
Tie-Stall system & $0.75^{\mathrm{b}} \pm 0.0$ & $1.00^{\mathrm{b}} \pm 0.0$ & $0.96^{\mathrm{a}} \pm 0.1$ \\
Loose system & $0.81^{\mathrm{b}} \pm 0.0$ & $1.12^{\mathrm{a}} \pm 0.0$ & $0.92^{\mathrm{b}} \pm 0.1$ \\
$\quad$ Average & & & \\
\hline$*$ a & Means & & \\
\hline
\end{tabular}

${ }^{*} \mathrm{a}, \mathrm{b}$ Means within each housing system and ${ }^{\mathrm{a}, \mathrm{b}, \mathrm{c}}$ Means within each season with different superscripts are significantly different $(P<0.01)$

\section{Physiological Parameters}

\subsection{Blood compositions and hormonal responses}

The effects of different housing systems and seasonal variations on total protein (TP, g/dl), albumin (g/dl), globulin (g/dl), total lipids concentrations (TL, mg/dl), glucose concentration $(\mathrm{mg} / \mathrm{dl})$ and thyroxine $\left(\mathrm{T}_{4}, \mu \mathrm{g} / \mathrm{dl}\right)$ are presented in Table (4).

The results of total protein (TP), albumin and globulin showed that there were insignificant housing differences between the two housing systems during winter, spring and summer. The results showed also that there were insignificant seasonal differences between the three seasons. However, summer season had lower values of $\mathrm{TP}$, albumin and globulin concentrations compared with winter and spring. The results revealed that the high AT in summer decreases the values of the three components. The results of total protein, albumin and globulin showed negative correlation coefficients with AT $(-0.14,-0.17$ and -0.20 , respectively). This result is in agreement with Shafie and Badreldin (1962) who found that the albumin content decreased in cattle $(-2.5 \%$ from $3.9 \mathrm{~g} / \mathrm{dl})$ when animals exposed directly to solar radiation. Lee et al. (1976) explained the phenomenon of increasing TP in low temperatures by globulin increase and primarily increase in the gamma fraction. Habeeb et al. (1992) stated that exposing farm animals to heat stress accompanied by biological changes including disturbance in protein and minerals metabolism.

On the contrary, El-Masry and Marai (1991) showed a significant decline in plasma TP in Friesian calves in winter $(4.8 \mathrm{~g} / \mathrm{dL})$ than in summer $(5.7 \mathrm{~g} / \mathrm{dL})$. 
Table 4. Seasonal means \pm S.E. of blood composition concentrations of young Friesian bulls kept in different housing systems

\begin{tabular}{|c|c|c|c|}
\hline \multirow{2}{*}{ Item/Housing types } & \multicolumn{3}{|c|}{ Seasons } \\
\hline & Winter & Spring & Summer \\
\hline \multicolumn{4}{|l|}{ TP (g/dl) } \\
\hline Tie-Stall system & $8.47^{\mathrm{a}} \pm 0.8$ & $7.96^{\mathrm{a}} \pm 0.5$ & $7.48^{a} \pm 0.6$ \\
\hline Loose system & $8.21^{\mathrm{a}} \pm 0.8$ & $9.07^{\mathrm{a}} \pm 0.5$ & $7.24^{\mathrm{a}} \pm 0.6$ \\
\hline Average & $8.34^{\mathrm{a}} \pm 0.6$ & $8.52^{a} \pm 0.5$ & $7.36^{\mathrm{a}} \pm 0.4$ \\
\hline \multicolumn{4}{|l|}{ Albumin (g/dl) } \\
\hline Tie-Stall system & $4.10^{\mathrm{a}} \pm 0.3$ & $4.51^{\mathrm{a}} \pm 0.8$ & $4.08^{\mathrm{a}} \pm 0.3$ \\
\hline Loose system & $4.12^{\mathrm{a}} \pm 0.3$ & $4.02^{\mathrm{a}} \pm 0.8$ & $4.11^{\mathrm{a}} \pm 0.3$ \\
\hline Average & $4.11^{\mathrm{a}} \pm 0.2$ & $4.26^{\mathrm{a}} \pm 0.3$ & $4.10^{\mathrm{a}} \pm 0.2$ \\
\hline \multicolumn{4}{|l|}{ Globulin (g/dl) } \\
\hline Tie-Stall system & $4.37^{\mathrm{a}} \pm 0.8$ & $3.46^{\mathrm{a}} \pm 0.8$ & $3.40^{\mathrm{a}} \pm 0.7$ \\
\hline Loose system & $4.09^{a} \pm 0.8$ & $5.06^{\mathrm{a}} \pm 0.8$ & $3.13^{\mathrm{a}} \pm 0.7$ \\
\hline Average & $4.23^{a} \pm 0.5$ & $4.28^{\mathrm{a}} \pm 0.6$ & $3.26^{\mathrm{a}} \pm 0.5$ \\
\hline \multicolumn{4}{|l|}{ TL (g/L) } \\
\hline Tie-Stall system & $2.85^{\mathrm{a}} \pm 0.3$ & $3.65^{\mathrm{a}} \pm 0.4$ & $3.45^{\mathrm{a}} \pm 0.4$ \\
\hline Loose system & $2.79^{a} \pm 0.3$ & $2.93^{\mathrm{a}} \pm 0.4$ & $3.16^{\mathrm{a}} \pm 0.4$ \\
\hline Average & $2.82^{\mathrm{a}} \pm 0.2$ & $3.29^{\mathrm{a}} \pm 0.3$ & $3.31^{\mathrm{a}} \pm 0.2$ \\
\hline \multicolumn{4}{|l|}{ Glucose (mg/dl) } \\
\hline Tie-Stall system & $56.25^{\mathrm{a}} \pm 3.7$ & $61.93^{\mathrm{a}} \pm 3.2$ & $35.76^{a} \pm 4.7$ \\
\hline Loose system & $58.41^{\mathrm{a}} \pm 3.7$ & $56.99^{\mathrm{a}} \pm 3.2$ & $37.25^{\mathrm{a}} \pm 4.7$ \\
\hline Average & $57.33^{a} \pm 2.6$ & $59.46^{\mathrm{a}} \pm 2.3$ & $36.51^{b} \pm 2.7$ \\
\hline \multicolumn{4}{|l|}{$\mathrm{T}_{4}(\mu \mathrm{g} / \mathrm{dl})$} \\
\hline Tie-Stall system & $2.95^{\mathrm{a}} \pm 0.3$ & $3.71^{\mathrm{a}} \pm 0.4$ & $2.23^{a} \pm 0.5$ \\
\hline Loose system & $3.13^{\mathrm{a}} \pm 0.3$ & $2.96^{\mathrm{a}} \pm 0.4$ & $2.34^{\mathrm{a}} \pm 0.5$ \\
\hline Average & $3.04^{\mathrm{ab}} \pm 0.2$ & $3.34^{\mathrm{a}} \pm 0.3$ & $2.27^{b} \pm 0.3$ \\
\hline
\end{tabular}
superscripts are significantly different $(P<0.01)$

The results of total lipids (TL) had the same trend of TP. However, winter season had lower values of TL ( $2.82 \mathrm{~g} / \mathrm{L})$ compared with spring and summer (3.29 and 3.31 $\mathrm{g} / \mathrm{L}$, respectively).compared with spring and summer. The results revealed that the low AT in winter had a suppressive effect on TL which has positive correlation coefficient with AT (0.26). This result is in agreement with the results of Collier et al. (1982) who reported that total lipids increased in hot weather as as result of increasing in ACTH and estrogens concentrations in heat stressed animals. Kandeal (2003) reported that such a phenomenon might be due to the increase in either body water content or utilization of fatty acids for energy production as a consequent of the decrease in glucose concentration. On the other hand, Ahmed (1990) reported higher concentrations of TL in Friesian calves during winter $(361.3 \mathrm{mg} / \mathrm{dl})$ than under the hot condition of summer $(278.5 \mathrm{mg} / \mathrm{dl})$. Ibrahim et al. (1993) explained that the reduction in TL during hot summer season might be attributed to high ambient temperature, which depresses the rate of thyroid gland secretion. Abdel-Samee et al. (1996) added that decreasing TL in summer in Friesian cows may be due to the 
metabolism of fat, protein, carbohydrate, minerals and vitamins that disturbed under heat stress conditions due to depression in both appetite and feed intake.

The results of glucose concentration had the same trend of TP and TL regarding the two housing systemsHowever, there was significant $(P<0.01)$ seasonal differences between the three seasons. Summer season had lower values of glucose concentrations $(36.51 \mathrm{mg} / \mathrm{dl})$ compared with winter $(57.33 \mathrm{mg} / \mathrm{dl})$ and spring $(59.46$ $\mathrm{mg} / \mathrm{dl})$ seasons. The results revealed that the high AT in summer had a suppressive effect on glucose concentration. Glucose concentration has negative correlation coefficient with AT (-0.20). This result is in agreement with the results of Shaffer et al. (1981), Kobeisy (1996) and Sayah (2005). Shaffer et al. (1981) interpreted the highly significant effect of hot temperature in reaching blood glucose of cattle, as result of increasing respiration rate, which causes a rapid utilization of blood glucose by the respiratory muscles resulting in a decreased blood glucose content (44.93 $\mathrm{mg} / \mathrm{dl}$ ) under heat stress. Kobeisy (1996) attributed the high level of blood glucose in winter to the effect of cool ambient temperature and the hormonal actions under cold conditions.

The results of thyroxine hormone $\left(\mathrm{T}_{4}\right)$ had the same trend of glucose concentrations regarding the two housing systems. The results also showed that there were high significant seasonal differences between the three seasons $(P<0.01)$. Summer season had lower values of $\mathrm{T}_{4}(2.27 \mu \mathrm{g} / \mathrm{dl})$ compared with winter $(3.04 \mu \mathrm{g} /$ $\mathrm{dl})$ and spring $(3.34 \mu \mathrm{g} / \mathrm{dl})$ seasons. The results revealed that the high AT in summer had a suppressive effect on $\mathrm{T}_{4}$. Thyroxine hormone concentration has negative correlation coefficient with AT (-0.35). This result is in agreement with the results of El-Masry and Habeeb (1989), Ashour et al. (2000) and Sayah (2005).Yousef and Johnson (1966) suggested that reduction in feed intake due to higher environmental temperatures causes depression in many physiological reactions including thyroid activity which is reduced in cows consuming the same amount of feed at high temperatures $\left(30{ }^{\circ} \mathrm{C}\right.$ and $\left.35{ }^{\circ} \mathrm{C}\right)$ as they did at $18{ }^{\circ} \mathrm{C}$ thermoneutral temperature. ElMasry and Habeeb (1989) added that the decrease in thyroid hormones levels during summer might be attributed to the decrease in thyroid stimulating hormone and glucocorticoid hormone. Scott et al. (1983) reported a negative relationship between plasma thyroxine concentration and rectal temperature but the initiation of night cooling at the time when rectal temperature reached the highest value was most beneficial in maintaining thermoneutral plasma thyroxine concentration, he suggested that strategically cooling the heat stressed cow could enhance her metabolic potential. On the other hand, Mohamed (1984) reported that there was a significant increase in $\mathrm{T}_{4}$ in pregnant cows exposed to $30{ }^{\circ} \mathrm{C}$ than animals exposed to $20{ }^{\circ} \mathrm{C}$, the same result was obtained by Collier et al. (1982).

\subsection{Body Reactions}

The effects of different housing systems and seasonal variations on rectal temperature $\left(\mathrm{RT},{ }^{\circ} \mathrm{C}\right)$, skin temperature $\left(\mathrm{ST},{ }^{\circ} \mathrm{C}\right)$ and respiration rate $(\mathrm{RR}, \mathrm{resp} . \mathrm{min}$.) are presented in Table (5).

The results of RT and RR showed significant $(P<0.01)$ differences between the two housing systems during the three seasons. The loose animals had higher values of RT and RR than restricted animals; these results indicated that the continous movements of the loose animals especially under hot weather may increase the core temperature, which resulted in increasing the physiological parameters. El-Nouty (1996) found that thermal stress causes a rise in core temperature and activate heat 
loss mechanism via panting and sweating. The respiration rate was found to be the most sensitive physiological response to the environmental conditions than other physiological responses, the results emphasized the comfort of tie-stall animals compared with loose animals. Kundu and Bhatnagar (1980) reported that the RR plays an important role in thermoregulatory mechanism amongst all the physiological reactions and body temperature comes next. The ST results of the two housing systems showed insignificant differences. However, the tie-stall animals had higher values than loose animals, this may due to the restricted animals are more affected to housing radiation and convection than loose animals. The results showed also significant seasonal differences $(P<0.01)$ between the three seasons for RT, ST and $\mathrm{RR}$, there are positive correlation coefficients between the three physiological parameters and AT $(0.37,0.86$ and 0.65 , respectively). The average RT, ST and RR of Friesian calves were significantly higher in summer season than in winter and spring. Similar results were obtained by Kandeal (2003). Abdel-Samee et al. (1996) found that RR of Friesian cows in summer increased by about $247 \%(P<0.01)$ than those of winter. Shafie and El-Sheikh Aly (1970) reported that there is a seasonal variation of Friesian body temperature. They reported that the increase in body reaction in Friesian cattle is the result of both gradual rise in atmospheric temperature and the variable increase in body activities of the animal.

Table 5. Seasonal means \pm S.E. of rectal temperature $\left(\mathrm{RT},{ }^{\circ} \mathrm{C}\right)$, skin temperature $\left(\mathrm{ST},{ }^{\circ} \mathrm{C}\right.$ ) and respiration rate (resp./min.) of young Friesian bulls kept in different housing systems

\begin{tabular}{|c|c|c|c|}
\hline \multirow{2}{*}{ Item/Housing types } & \multicolumn{3}{|c|}{ Seasons } \\
\hline & Winter & Spring & Summer \\
\hline \multicolumn{4}{|l|}{ RT $\left({ }^{\circ} \mathrm{C}\right)$} \\
\hline Tie-Stall system & $38.46^{\mathrm{b}} \pm 0.1$ & $38.64^{b} \pm 0.1$ & $38.84^{b} \pm 0.1$ \\
\hline Loose system & $38.74^{\mathrm{a}} \pm 0.1$ & $38.80^{\mathrm{a}} \pm 0.1$ & $39.18^{a} \pm 0.1$ \\
\hline Average & $38.60^{\mathrm{c}} \pm 0.1$ & $38.72^{b} \pm 0.1$ & $39.01^{\mathrm{a}} \pm 0.1$ \\
\hline \multicolumn{4}{|l|}{ ST $\left({ }^{\circ} \mathrm{C}\right)$} \\
\hline Tie-Stall system & $29.25^{\mathrm{a}} \pm 0.2$ & $32.04^{\mathrm{a}} \pm 0.4$ & $34.62^{\mathrm{a}} \pm 0.2$ \\
\hline Loose system & $29.23^{\mathrm{a}} \pm 0.2$ & $31.38^{\mathrm{a}} \pm 0.4$ & $34.42^{\mathrm{a}} \pm 0.2$ \\
\hline Average & $29.24^{b} \pm 0.2$ & $31.71^{\mathrm{a}} \pm 0.2$ & $34.52^{\mathrm{a}} \pm 0.2$ \\
\hline \multicolumn{4}{|l|}{ RR (resp. /min.) } \\
\hline Tie-Stall system & $27.58^{b} \pm 1.5$ & $39.19^{b} \pm 1.6$ & $58.50^{\mathrm{b}} \pm 2.3$ \\
\hline Loose system & $37.86^{\mathrm{a}} \pm 1.5$ & $46.75^{\mathrm{a}} \pm 1.6$ & $61.50^{\mathrm{a}} \pm 2.3$ \\
\hline Average & $32.73^{\mathrm{c}} \pm 1.2$ & $42.97^{b} \pm 1.2$ & $60.00^{\mathrm{a}} \pm 1.2$ \\
\hline
\end{tabular}
with different superscripts are significantly different $(P<0.01)$

\section{Economical Efficiency}

Figure (2) shows the differences of body weight gain values between the tie-stall and loose animals during the experimental period. The differences started with $0.1 \mathrm{~kg}$ as a difference between the average initial weights $(123 \mathrm{~kg}$ for tie-stall animals and $122.9 \mathrm{~kg}$ for the loose animals) and ended with $42.2 \mathrm{~kg}$ in favor of the tie-stall animals as a difference between the average final weights $(412.33 \mathrm{~kg}$ for tie-stall animals and $370.29 \mathrm{~kg}$ for the loose animals). Those differences tend to increase linearly with increasing age. 


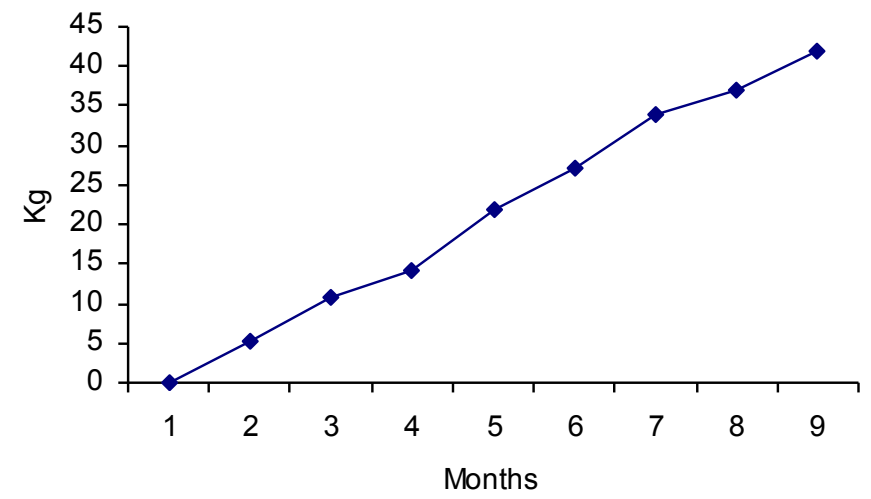

Fig. 2. Differences of body weight gain values between the tie-stall and loose animals during the experimental period

Data in Table (6) show that the total feed intake in tie-stall animal group was higher than loose animal group (15.05 kg and $13.85 \mathrm{~kg}$, respectively). This result is in agreement with El-Ashry et al. (1972) using data on growth rate of Friesian males in Egypt, found that increasing the proportion of concentrations in the ration improved daily gain in weight and feed efficiency. These results also showed that the cost of $\mathrm{kg}$ body weight gain was decreased by tie-stall group (LE 12.20) compared with loose animal group (LE 13.03). Furthermore, total revenue was increased by $21.84 \%$ with tie-stall group than that of loose animal group.

Table 6. Feed intake and economic efficiency of young Friesian bulls kept in different housing systems

\begin{tabular}{|c|c|c|}
\hline \multirow{2}{*}{ Item } & \multicolumn{2}{|c|}{ Animal housing systems } \\
\hline & Tie-stall system & Loose system \\
\hline \multicolumn{3}{|l|}{ Avg. feed intake /head/day (Kg): } \\
\hline CFM & 6.15 & 5.80 \\
\hline Berseem hay & 0.60 & 0.60 \\
\hline Berseem & 7.0 & 6.25 \\
\hline Rice straw & 1.30 & 1.20 \\
\hline Total feed intake & 15.05 & 13.85 \\
\hline \multicolumn{3}{|l|}{ Economic efficiency (LE): } \\
\hline Cost of feed intake/animal/day & 12.44 & 11.73 \\
\hline Cost of Kg ration & 1.21 & 1.18 \\
\hline Price of Kg body gain & 16.00 & 16.00 \\
\hline Cost of Kg body gain & 12.20 & 13.03 \\
\hline Total revenue & 3.80 & 2.97 \\
\hline
\end{tabular}




\section{CONCLUSION}

According to the results of this study, it could be concluded that keeping animals in tie-stall system inside a fully shaded barn having dry concrete floor with good drainage and well-ventilated area give better growth performance than keeping animals in loose system under the same environmental conditions. Moreover, the effect of housing systems is limited mainly to growth performance without influencing blood composition animals. In addition, the tie-stall group was more economically efficient compared with the loose animal group. The total revenue was increased with tie-stall group compared with loose animal group (LE 3.80 and LE 2.97 , respectively).

\section{REFERENCES}

Abdel-Samee, A. M, E. L. Abou-Fandoud and K. M. El-Gendy, 1996. The role of probiotics in ameliorating heat load in lactating Friesian during summer under North Sinai conditions. Egyptian J. Anim. Prod., 33: 277 - 286.

AETG (Agriculture Engineering Technology Guide), 1980. Livestock and poultry heat stress indices, Clemson, Univ., Clemson, SC.29634, USA.

Ahmed, H. I. A., 1990. Studies on alleviating thermal stress in imported Friesian cattle under Egyptian environmental conditions. Ph.D. Thesis, Fac. Agric., Zagazig Univ., Egypt.

Ashour, G., 1990. Water balance in bovine as related to heat regulation. Ph. D. Thesis, Fac. Agric., Cairo Univ., Egypt.

Ashour, G., A. S. El-Nagar, M. M. Yousef and H. M. Mourad, 2000. Growth performance and metabolic profile of Egyptian cattle and buffalo calves. Proc. $3^{\text {rd }}$ All Africa Conf. Anim. Agric. and 11 th Conf. Egypt. Soc. Anim. Prod., Alexandria, Egypt.

Ashour, G., F. I. Omran, M. M. Yousef and M. M. Shafie, 2007. Effect of thermal environment on water and feed intakes in relationship with growth of buffalo calves. Egyptian J. Anim. Prod., 44: 25 - 33.

Bianca, W., 1965. Reviews of the progress of dairy science. Section A, Physiology: cattle in a hot environment. J. Dairy Res., 32: 291 - 345.

Chua, B., E. Coenen, J. van Delen and D. M. Weary, 2002. Effects of pair versus individual housing on the behavior and performance of dairy calves. J. Dairy Sci. $85: 360$ - 264.

Collier, R.J., D. K. Beede, W. W. Thatcher, I. A. Israel and C. J. Wilcoa, 1982. Influence of environment and its modification on dairy animals health and production. J. Dairy Sci., 65: 2213 - 2227.

Daader, A. H., I. F. M. Marai, A. A. M. Habeeb and H. M. Yousef, 1989. Improvement of growth performance of Friesian calves under Egyptian subtropical conditions. 1. Internal cooling techniques using diuretics and drinking cool water. Proc. of $3^{\text {rd }}$ Egyptian-British Conf. on Animal, Fish and Poultry Production, Alexandria, Egypt. 2: 595 - 605.

El-Ashry, M. A., H. H. Mogawer and S. S. Khishin, 1972. Comparative study of meat production from cattle and buffalo male claves. 1- Effect of roughage concentrate ratio in ration on rate of gain and feed efficiency of native cattle. Egyptian J. Anim. Prod., 12: 99 - 107. 
EL-Masry, K. A. and A. A. Hebeeb, 1989. Thyroid function in lactating Friesian cows and water buffaloes under winter and summer Egyptian conditions. Proc. of $3^{\text {rd }}$ Egyptian-British Con. on Animal, Fish and Poultry Production, Alexandria, Egypt.

EI-Masry, K. A. and I. F. Marai, 1991. Comparison between Friesian and water buffaloes in growth rate, milk production and some blood constituents, during winter and summer conditions of Egypt. Anim. Prod., 53:38 - 43.

El-Nouty, F. D., 1996. Heat stress and milk production: Means of alleviation. Egyptian J. Anim. Prod., Suppl. Issue, 33: 539 - 552.

Habeeb, A. A., I. F. M. Marai and T. H. Kamal, 1992. Heat stress. In: Farm Animals and Environment. Phillips and Piggins (Eds.), CAB International, UK.

Ibrahim, A. I., A. Abdel-Raheem, M. E. Abdel-Fattah, K. Khalid and A. Kamal., 1993. Some blood constituents of camels in relation to seasonal variations. Zagazig Vet. J., 21:936 - 942.

Johnson, H. D., 1987. Bioclimates and livestock. In: Bioclimatology and the Adaptation of Livestock. Johnson (Ed.), Elsevier Science Publishers, Amsterdam, The Netherlands.

Kandeal, M. H. H., 2003. Performance of Friesian calves under different managerial conditions. M.Sc. Thesis, Fac. Agric., Zagazig Univ., Egypt.

Kobeisy, M. A., 1983. Adaptation of Friesian cattle in Upper Egypt. M. Sc. Thesis, Fac. Agric., Assiut Univ., Egypt.

Kobeisy, M. A., 1996. Physiological responses of water buffaloes to cool ambient temperature and housing practice. Egyptian J. Anim. Prod., 33:257 - 267.

Kundu, A. K. and D. S. Bhatnagar, 1980. Physiological reactions in different genetic groups of crossbreds during summer. Indian J. Dairy Sci., 33:403 - 405.

Lawrence, N. G., 1994. Beef cattle housing. In: Livestock Housing. Wathes, C, and Charles, D. (Eds.), CAB international, UK, pp. 339 - 357.

Lee, J. A., J. D. Roussel and J. F. Beatty, 1976. Effect of temperature-season on bovine adrenal cortical function, blood cell profile and milk production. J. Dairy Sci., 59:104 - 108 .

Mader, T.L., M.S. Davis and T. Brown-Brandl, 2006. Environmental factors influencing heat stress in feedlot cattle. J. Anim. Sci., 84:712 - 719.

Mitlohner, F. M, M. L. Galyean and J. J. McGlone, 2002. Shade effects on performance, carcass traits, physiology, and behavior of heat-stressed feedlot heifers. J. Anim. Sci., 80:2043 - 2050.

Mohamed, A. A., 1984. Some physiological responses of pregnant cows exposed to heat stress. Indian J. Anim. Sci., 54:1072 - 1074.

Morrison, S. R., 1983. Ruminant heat stress: effect on production and means of alleviation. J. Anim. Sci., 57:1594 - 1599.

Muhamed, Y. B., M. P. Hoffman and H. L. Self, 1983. Influence of different rations of corn and corn silage, housing systems and seasons on the performance of feedlot steers. J. Anim. Sci., 56:747 - 754.

Nardone, A., B. Ronchi, N. Lacetera and U. Bernabucci, 2006. Climatic effects on productive traits in livestock. Veterinary Research Communications, 30: 75 - 81.

NRC (1981). National Research Council. Effect of environment temperature on nutrient requirements of domestic animals. Natl Acad Press. Washington, DC, USA. 
Prawl, Z.I., F. N. Owens and D. R. Gill, 1998. Effects of pen size or housing on performance and carcass characteristics of feedlot steers. Anim. Sci. Res. Report, $83-88$.

Pusillo, G. M., M. P. Hoffman and H. L. Self, 1991. Effects of placing cattle on feed at two-month intervals and housing on feedlot performance and carcass grades. J. Anim. Sci., 69:442 - 50.

Sakaguchi, Y. and J. B. Gaughan, 2002. The effect of heat stress on carcass characteristics of beef cattle. Reproductive loss in farm animal during heat stress. In: Proc. $15^{\text {th }}$ Conf. Biometeorol. Aerobiol, pp.114 - 115.

SAS, 1996. SAS user's guide, statistics, SAS Inst. Inc., Cary, North California, USA.

Sayah, M. S., 2005. Effect of housing conditions on Friesian calves performance. Ph.D. Thesis, Fac. Agric., Cairo Univ., Egypt.

Scott, I. M., H. D. Johnson and G. L. Hahn, 1983. Effect of programmed diurnal temperature cycles on plasma thyroxine level, body temperature, and feed intake of Holstein dairy cows. Int. J. Biometeor., 27:47 - 62.

Shaffer, D., J. D. Roussel and K. L. Koonce, 1981. Effects of age, temperature season and breed on blood characteristics of dairy cattle. J. Dairy Sci., 64:62 - 70 .

Shafie, M. M. and A. L. Badreldin, 1962. The role of blood in regulating body heat in bovines. Egyptian J. Anim. Prod., 2:61 - 76.

Shafie, M. M. and L. M. M. El-Sheikh Aly, 1970. Heat tolerance of Friesian cattle under Egyptian climatic conditions. Egyptian J. Anim. Prod., 10:99 - 114.

Terosky, T. L., L.L. Wilson, C. L. Stull, and W. R. Stricklin, 1997. Effects of individual housing design and size on special-fed Holstein veal calf growth performance, hematology, and carcass characteristics. J. Anim. Sci., 75: 1697 1703.

West, J. W., 2003. Effects of heat-stress on production in dairy cattle. J. Dairy Sci., $86: 2131-2144$.

Yousef, M. K. and H. D. Johnson, 1966. Blood thyroxine degradation rate of cattle as influenced by temperature and feed intake. Life Sci., 42: 1349 - 1363. 


\title{
تأثير نظم الإيواء المختلفة والتباينات الموسمية على أداء النمو والمؤشرات الفسيولوجية والكفاءة الإقتصادية لعجول الفريزيان
}

\author{
محمود سيد صياح، سمير على إبراهيم، أحمد محمد الجعفراوى، عبد الستار عبد العزيز شتا، أحمد

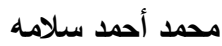

\section{معهز بحوث الإتتاج الحيوانس، مركز البحوث النزاعية، وزارة النزاعة، الجيزة، مصر}

أستخدم فى هذه الدراسة 17 ذكر فريزيان على عمر Y-Y شهور و متوسط وزن بآ ا كجم وذللك لدراسة

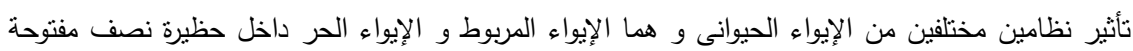

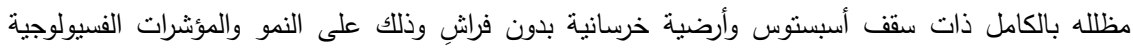
للعجول خلال فصول الثتاء و الربيع و الصيف.

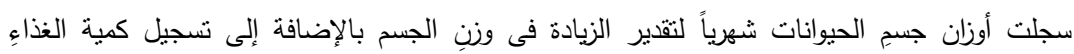

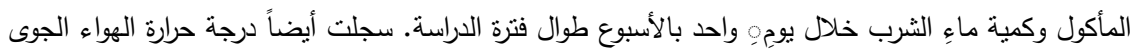

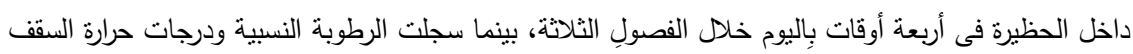

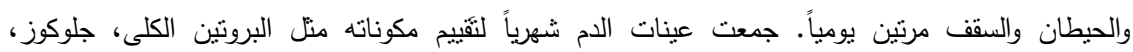

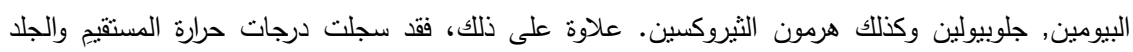

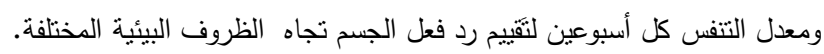

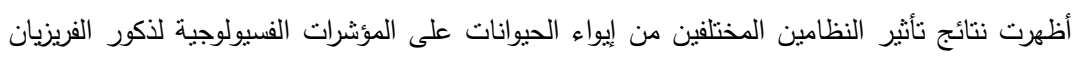

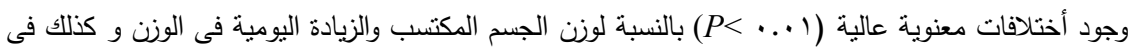

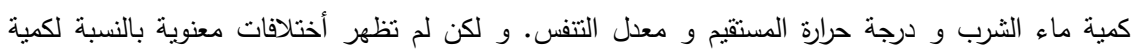

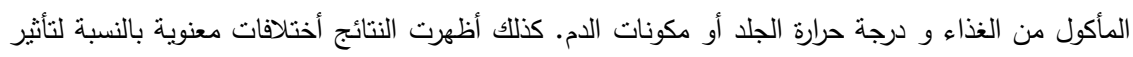

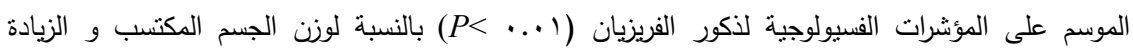

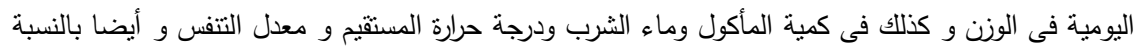

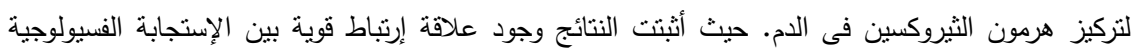
الحيوانات والظروف البيئية. وقد أظهرت الحيوانات المربوطة نتائج أفضل بالمقارنة بالحيوانات الحرة.

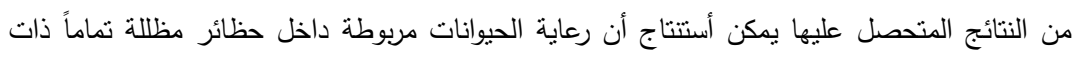
أرضية خرسانية و نظام صرف جيد و تهوية جيدة بجانب مساحات مناسبة داخل الحظبرة تؤدى إلى نمو أفضلِ

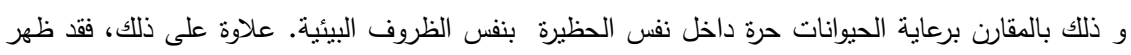

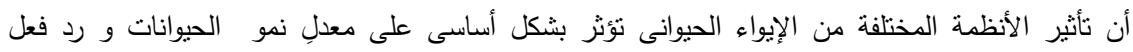

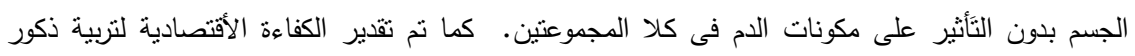




$$
\begin{aligned}
& \text { الفريزيان تحت النظامين المختلفين من الإيواء و وجد أن قيمة العائد أعلى عند تربية العجول مربوطة عن }
\end{aligned}
$$

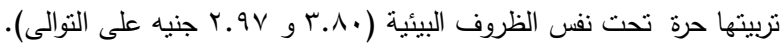

